PEMBENTUKAN MATERIAL (METAL FORMING)

HOT WORKING PROCESS DAN COLD WORKING PROCESS

PEMBENTUKAN MATERIAL (METAL FORMING)

HOT WORKING PROCESS DAN COLD WORKING

PROCESS

\title{
Wahyu Hidayat
}

Metal Forming dapat diklasifikasikan menjadi dua kelompok menurut proses pengerjaannya, yaitu :

1. Hot Working Process (Pengerjaan Dalam Kondisi Panas)

Pada proses pengerjaan Hot Working Process ini akan terjadi kenaikan

tegangan luluh, kenaikan nilai kekerasan material (logam baja), dan

penurunan nilai keuletan material.

2. Cold Working Process (Pengerjaan Dalam Kondisi Dingin)

Proses pembentukan logam secara plastis dengan temperatur pengerjaan di bawah temperatur rekristalisasi.

PENGKLASIFIKASIAN METAL FORMING

PROSES PENGERJAAN PANAS

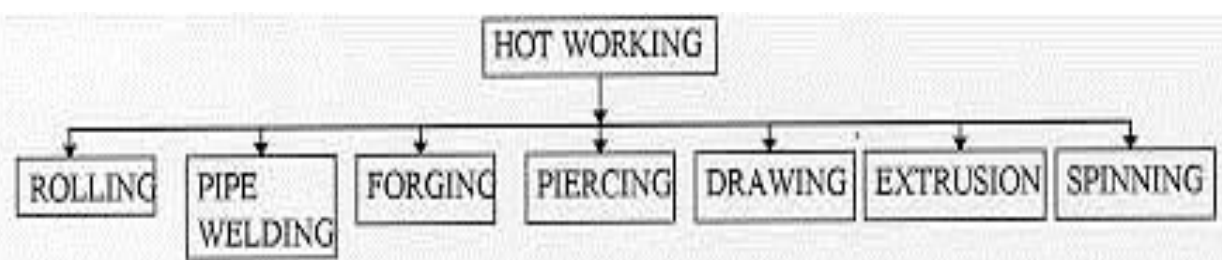

Gambar 2.8 [www.google.com pembentukan material 


\section{PEMBENTUKAN MATERIAL (METAL FORMING) HOT WORKING PROCESS DAN COLD WORKING PROCESS}

1. Hot Working Process (Pengean Dalam Kondisi Panas)

Pada proses pengerjaan ini tidak terjadi kenaikan tegangan lulur, kekerasan dan penurunan keuletan bahan. Beberapa keuntungan dari pengerjaan dalam kondisi panas diantaranya adalah :

1.Energi / Gaya yang dibutuhkan untuk pembentukan benda kerja lebih kecil.

2.Flow ability tinggi

3.Difusi cepat

4.Blow hole dan porosity dapat diminimalisir

5.Butir-butir lebih halus

6.Ductikity dan touhness meningkat

Selain memiliki beberapa keunggulan atau kelebihan, pengerjaan dalam kondisi panas juga memiliki kelemahan diantaranya adalah :

1.Terjadi oksidasi

2.Decarburization permukaan

3.Toleransi besar

4.Struktur dan sifat logam tidak uniform

5.Perlu peralatan tahan panas

6.Kontaminasi tidak dapat dikurangi

PENGKLASIFIKASIAN METAL FORMING

PROSES PENGERJAAN DINGIN

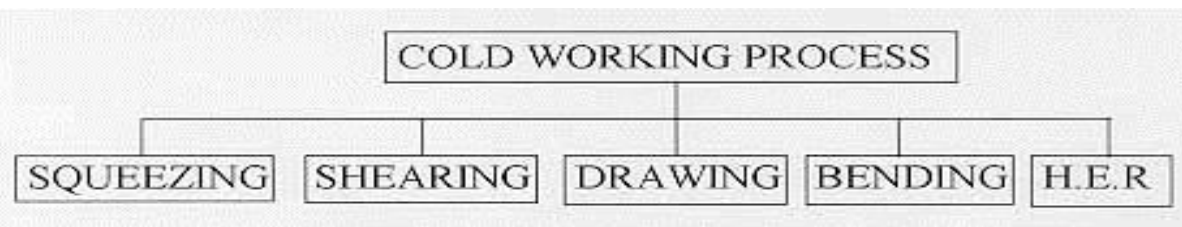

Gambar 2.9 [www.google.com pembentukan material] 


\section{PEMBENTUKAN MATERIAL (METAL FORMING) HOT WORKING PROCESS DAN COLD WORKING PROCESS}

\section{Cold Working Process (Pengerjaan Dalam Kondisi Dingin)}

Pada proses pengerjaan dingin ini pembentukan logam secara plastis dilakukan dengan temperatur pengerjaan di bawah temperatur rekristalisasi.

Keuntungan pengerjaan dalam kondisi dingin

- Tidak memerlukan pemanas

- Hasil permukaan akhir lebih baik

- Kontrol dimensi baik

- Kontaminasi dapat dikurangi

- Sifat strenght, fatique dan wear meningkat

Kelemahan pengerjaan dalam kondisi dingin

- Gaya tekan yang dibutuhkan lebih besar

- Peralatan mesin berat

- Sifat ductility menurun

- Permukaan logam harus bersih

- Tegangan sisa yang tidak diinginkan terjadi

Metal forming juga dapat diklasifikasikan menjadi dua kelompok menurut benda kerjanya,yaitu :

1. Bulk or messive forming

Material yang dideformasi berbentuk gumpalan

2. Sheet metal forming

Material yang dideformasi berbentuk lembaran. 


\section{PEMBENTUKAN MATERIAL (METAL FORMING) \\ HOT WORKING PROCESS DAN COLD WORKING PROCESS}

\section{Bulk or Messive Forming}

\section{A. Proses Rolling}

Proses ini dilakukan dengan cara melewatkan material melalui celah antara dua buah rol yang berputar dengan arah putaran yang berlawanan. Penampang material sesudah melewati celah akan berubah sesuai dengan bentuk rol yang digunakan.

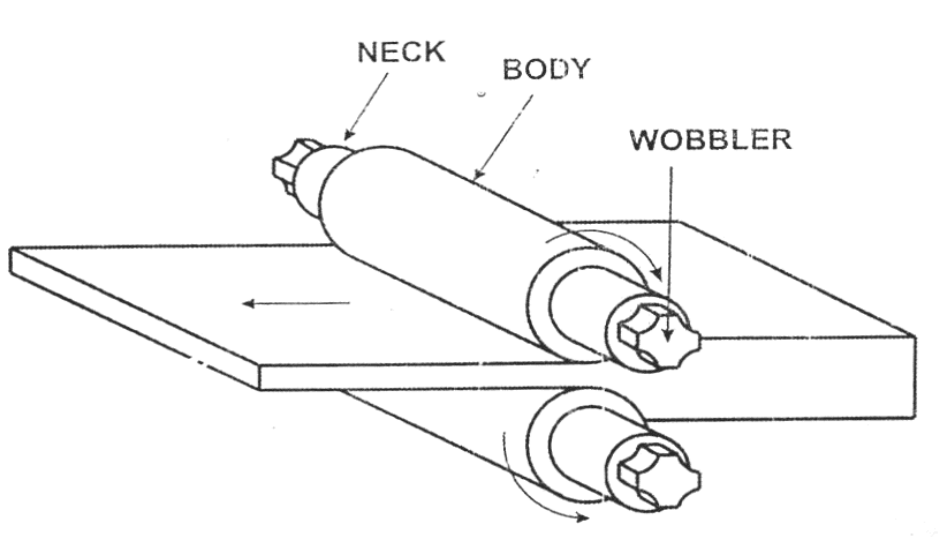

Gambar 2.10 [www.google.com pembentukan material]

\section{B. Proses Forging}

Proses Pembentukan material dengan mendeformasi material dengan cara dipukul, ditekan atau ditempa dengan menggunakan cetakan, atau bisa saja tanpa menggunakan cetakan.

Forging dapat dikelompokan,menjadi 2,yaitu :

\section{Open die forging}

Material yang dibentuk diletakan diantara dua buah permukaan rata tanpa menggunakan cetakan. Material ditempa secara berkesinambungan dengan arah longitudinalnya,sehingga material akan bertambah panjang dan 


\section{PEMBENTUKAN MATERIAL (METAL FORMING) \\ HOT WORKING PROCESS DAN COLD WORKING PROCESS}

luas penampang material akan berkurang. Contoh-contoh proses operasi yang termasuk dalam open die forging adalah: upsetting, drawing out, fullering, cutting off, dan piercing.

Drawing Out:
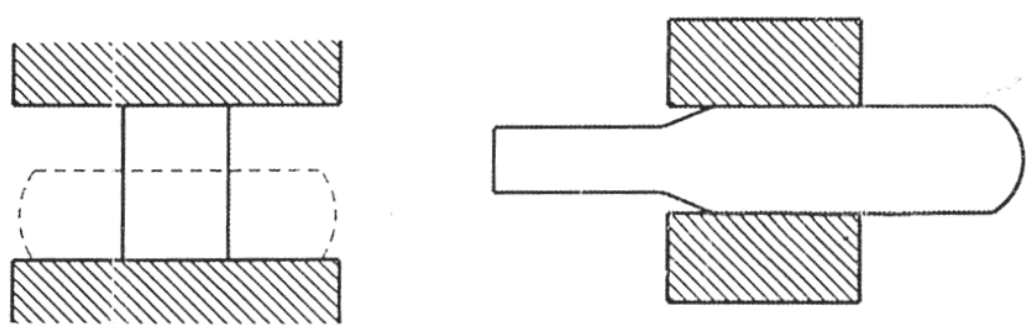

Piercing (Membuat lubang pada material)
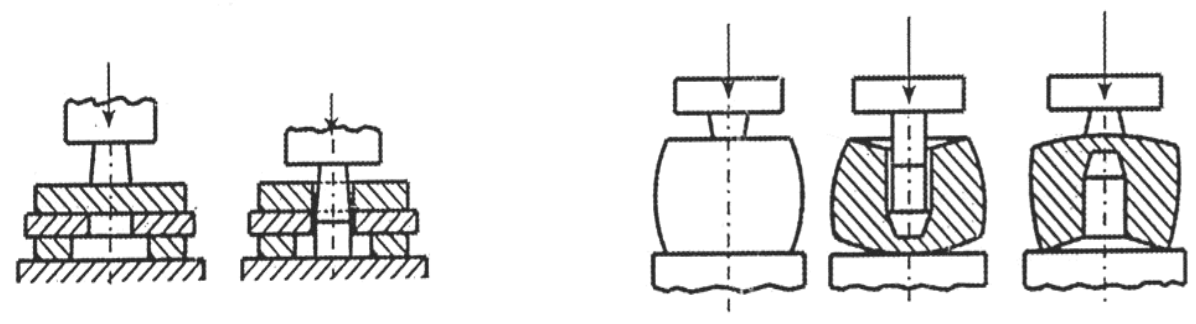

Cutting Off (memisahkan material menjadi 2 bagian)
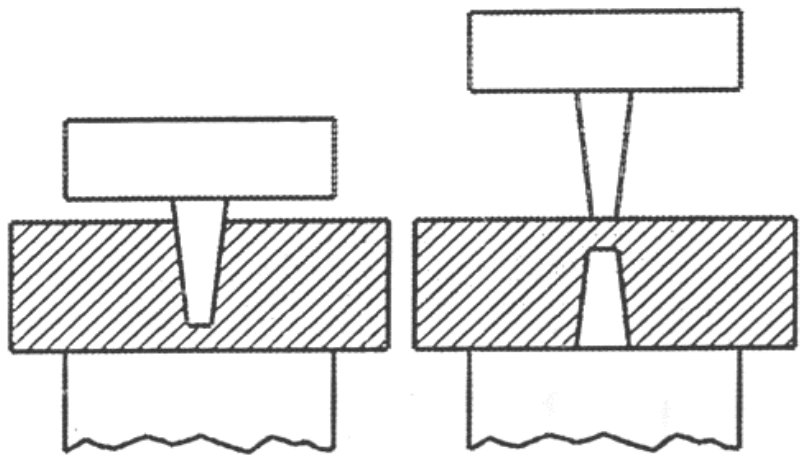

Gambar 2.11 [www.google.com pembentukan material] 


\section{PEMBENTUKAN MATERIAL (METAL FORMING) \\ HOT WORKING PROCESS DAN COLD WORKING PROCESS}

\section{Close die forging}

Material yang dibentuk diletakan di dalam cetakan selama proses pembentukan dilakukan,sehingga bentuk yang diinginkan sesuai dengan bentuk dei nya tersebut.

Proses ini sesuai digunakan untuk membuat produk dengan jumlah produk yang banyak (produksi massa).

Keunggulan Close die forging :

- Ketepatan prosesnya tinggi (variasi produk yang dihasilkan relatif sempit)

- Permukaan hasil proses baik.

Kelemahan close die forging :

- $\quad$ Tidak dapat digunakan untuk membuat produk yang bentuknya rumit.

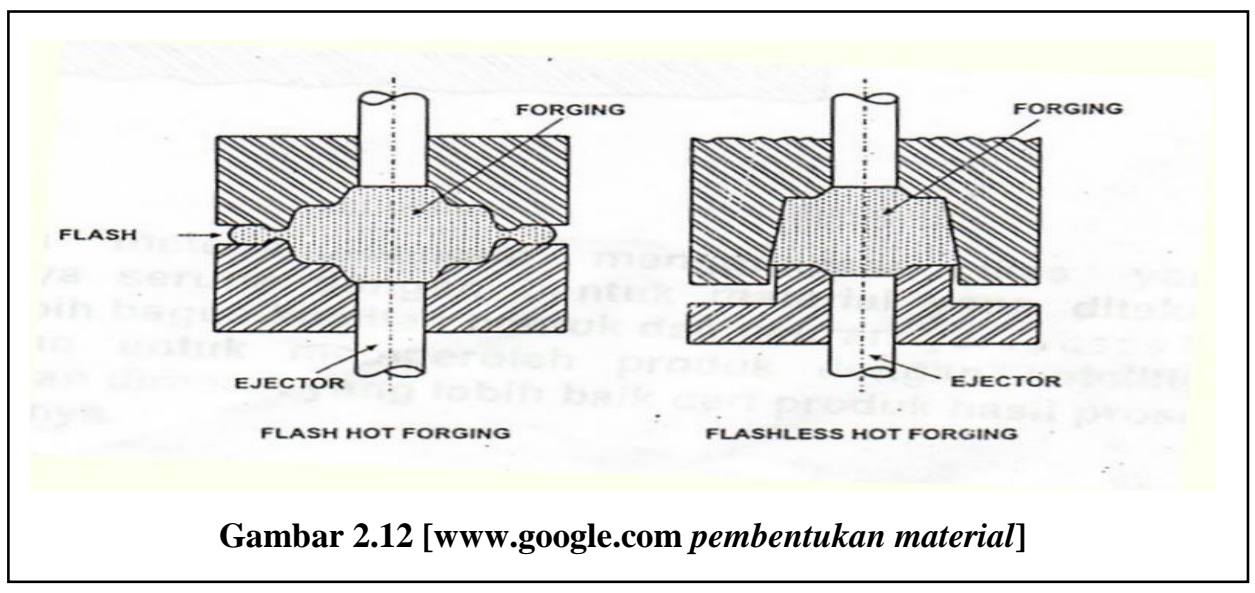

\section{Proses Extrusion}

Proses Pembentukan logam dengan cara menekan atau mendorong material,yang tertampung pada suatu wadah dan yang salah satu dindingnya mempunyai celah,sehingga material keluar melalui celah cetakan tersebut. Bentuk material yang diinginkan sesuai dengan bentuk celah dei tersebut.

Material yang digunakan dalam proses extrusion ini adalah material seperti : Tembaga,alumunium,dll. 


\section{PEMBENTUKAN MATERIAL (METAL FORMING) HOT WORKING PROCESS DAN COLD WORKING PROCESS}

Keunggulan extrusion :

- Produk yang dihasilkan mempunyai ketelitian dimensi yang tinggi.

- Dapat digunakan untuk membuat produk dengan bentuk penampang yang komplek dari material yang mempunyai plastisitas rendah.

Kelemahan extrusion :

- Produktivitas rendah

- Umur perkakas pendek

Jenis - Jenis Ekstrusi:

\section{Direct Extrusion}

Arah penekanan material searah dengan aliran material keluar cetakan. Pada akhir langkah penekanan tidak semua material keluar melalui cetakan. Material tersebut perlu dipotong dan dikeluarkan dari cetakan.

Keuntungan Direct Extrusion:

> Produk yang dihasilkan mempunyai ketelitian dimensi yang tinggi.

Dapat digunakan untuk membuat produk dengan bentuk penampang yang komplek dari material yang mempunyai plastisitas rendah

Keterbatasan Direct Extrusion

$>$ Produktifitas rendah

$>$ Umur perkakas pendek

$>$ Harga perkakasnya mahal 


\section{PEMBENTUKAN MATERIAL (METAL FORMING) \\ HOT WORKING PROCESS DAN COLD WORKING PROCESS}

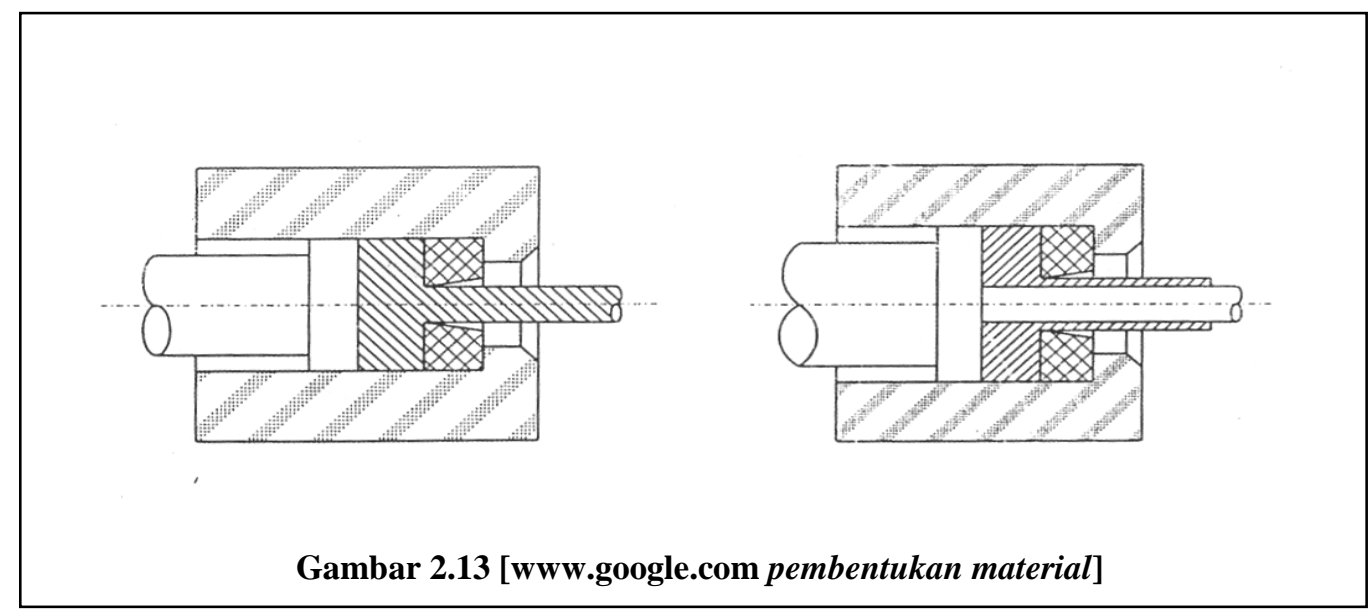

\section{Indirect Extrusion}

Celah disatukan dengan alat penekan yang berongga. Celah didorong kedalam wadah berisi material. Material keluar berlawanan dengan arah penekanan.

Pada indirect extrusion hamper tidak terjadi gesekan antara dinding wadah dan material yang ditekan. Oleh karenanya gaya penekanan pada indirect extrusion lebih kecil dibandingkan dirct extrusion.

Dan sisa material yang tidak terekstrusi lebih sedikit dibandingkan dengan direct extrusion.

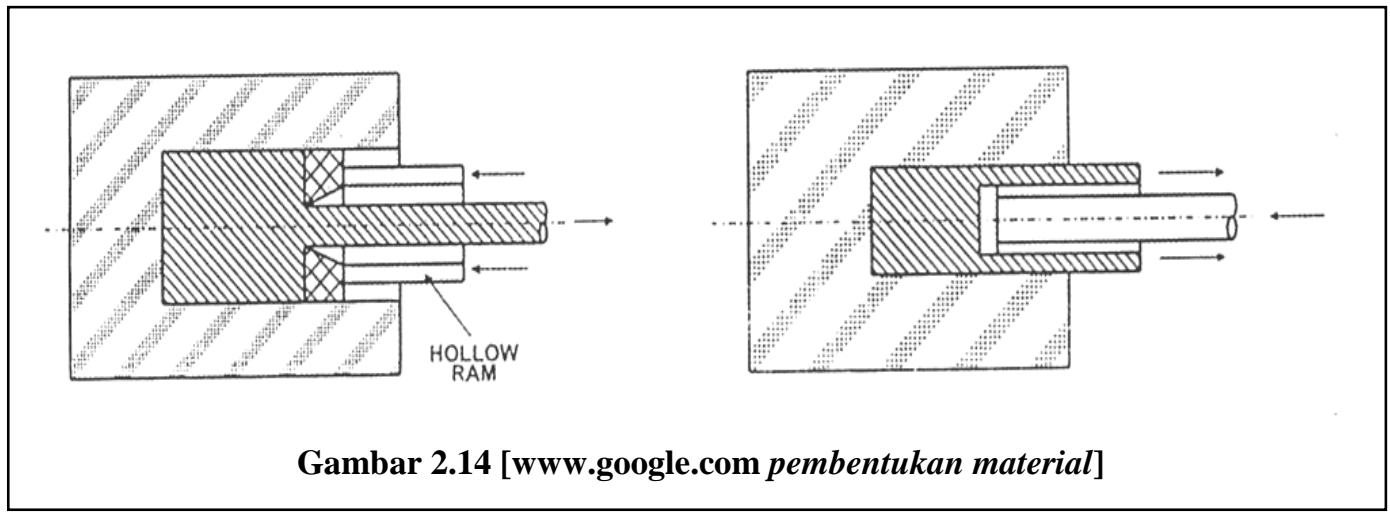




\section{PEMBENTUKAN MATERIAL (METAL FORMING) HOT WORKING PROCESS DAN COLD WORKING PROCESS}

\section{Impact Extrusion}

Memberikan beban tiba-tiba (menjatuhkan penekan dari ketinggian tertentu) pada suatu material yang tertampung pada wadah yang dangkal sehingga material tersebut mengalir ke sekeliling penekan, atau mengalir keluar melalui celah cetakan. Ada tiga cara melakukan impact extrusion, yaitu: forward, reverse, dan combination.
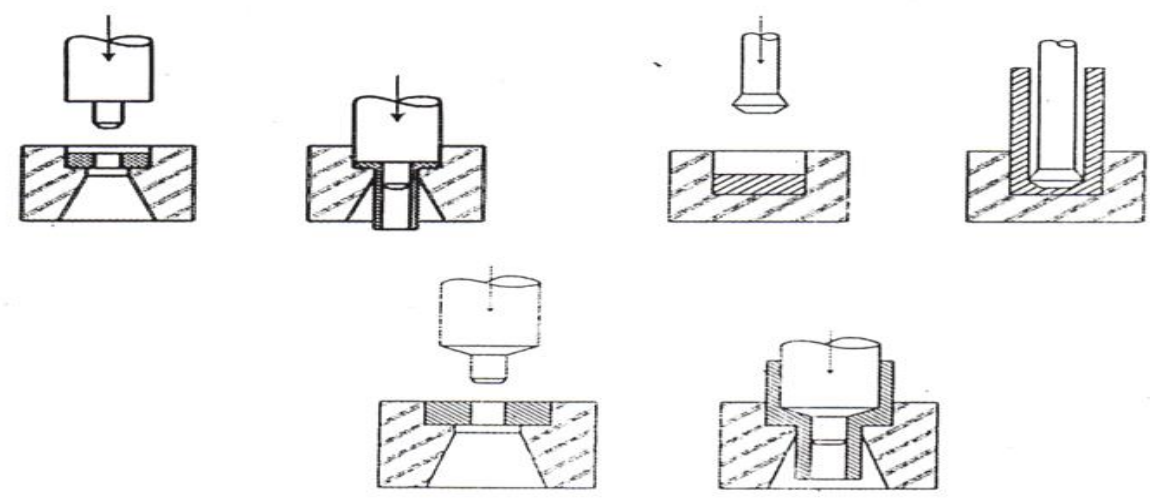

Gambar 2.15 [www.google.com pembentukan material]

\section{Hydrostatic Extrusion}

Material sebelum di ekstrusi dibentuk terlebih dahulu sehingga sesuai dengan bentuk cetakan. Material dikelilingi oleh fluida bertekanan tinggi. Bila plunger ditekan, maka tekanan fluida akan meningkat dan menyebabkan material keluar dari cetakan.

Tidak ada gesekan antara material dengan dinding wadah, dan gesekan antara material dan dinding wadah sangat kecil. 
PEMBENTUKAN MATERIAL (METAL FORMING)

HOT WORKING PROCESS DAN COLD WORKING PROCESS

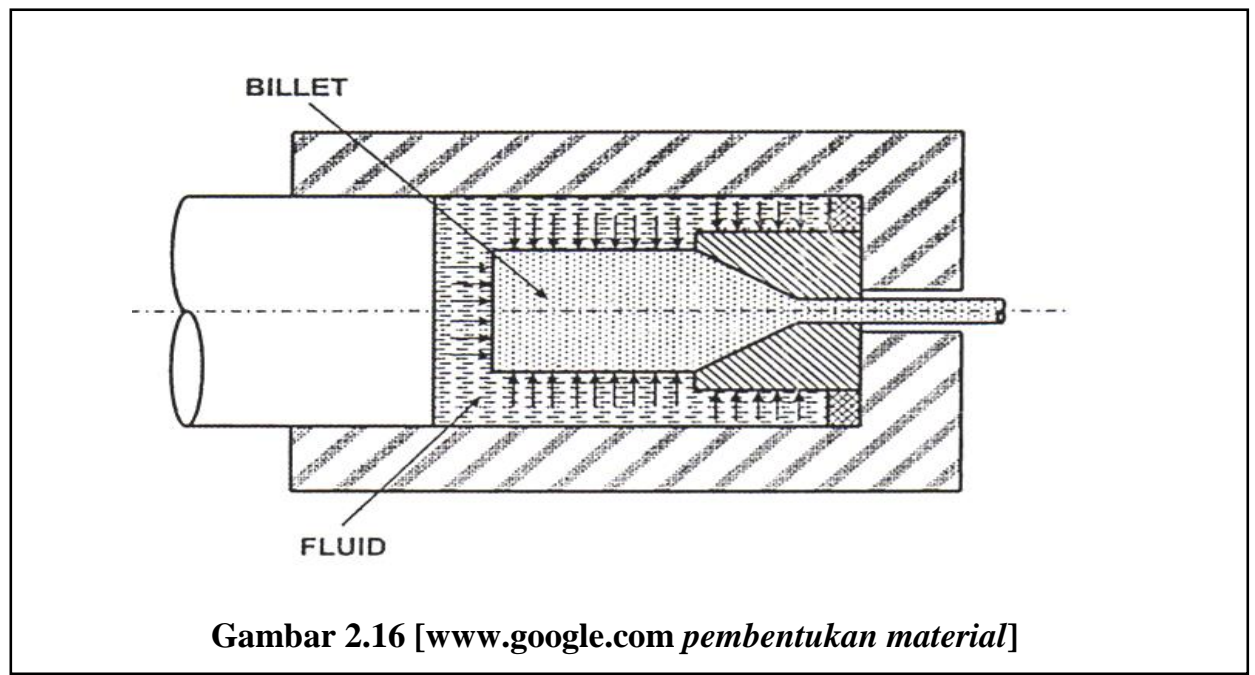

\section{Proses sheet metal forming :}

\section{A. Shearing}

Proses Pemotongan material yang mana alur pemotongnya berupa garis lurus.

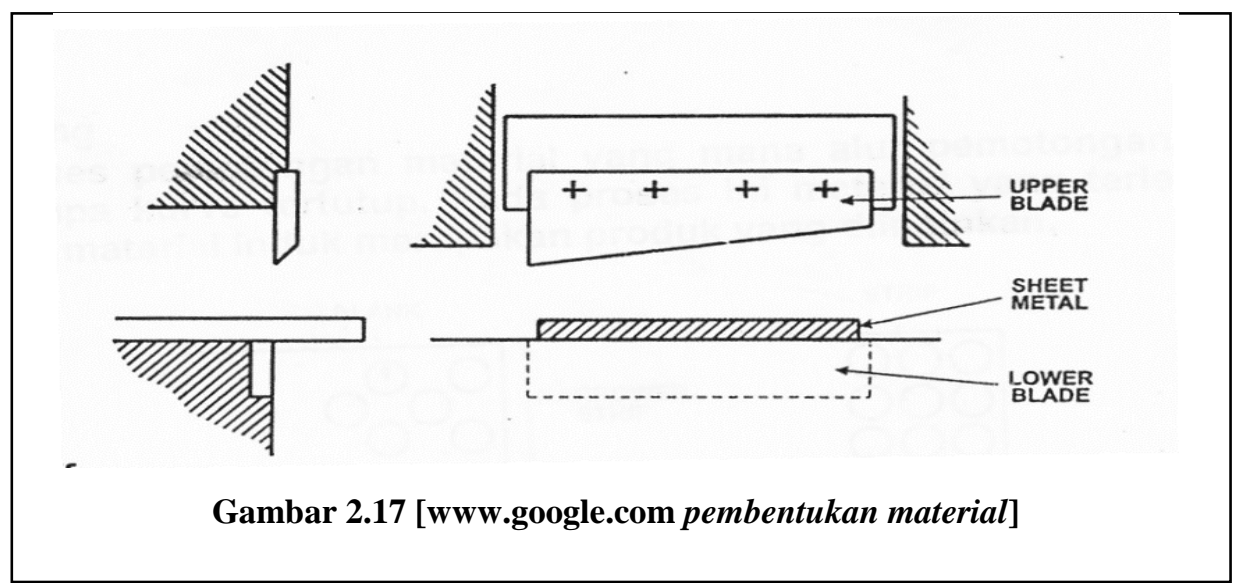

\section{B. Bending}

Proses tekuk dengan cara memberikan momen lentur pada bagian-bagian tertentu benda kerja,sehingga pada bagian-bagian tersebut terjadi pembengkokan.

Pada proses ini dapat digunakan proses hot working atau cold working,karena tergantung pada materialnya yang akan diproses. Agar pada bagian yang akan 


\section{PEMBENTUKAN MATERIAL (METAL FORMING) HOT WORKING PROCESS DAN COLD WORKING PROCESS}

dibengkokan tidak terjadi penipisan pada bagian tersebut,maka diberi tonjolan sebelum dibengkokkan.

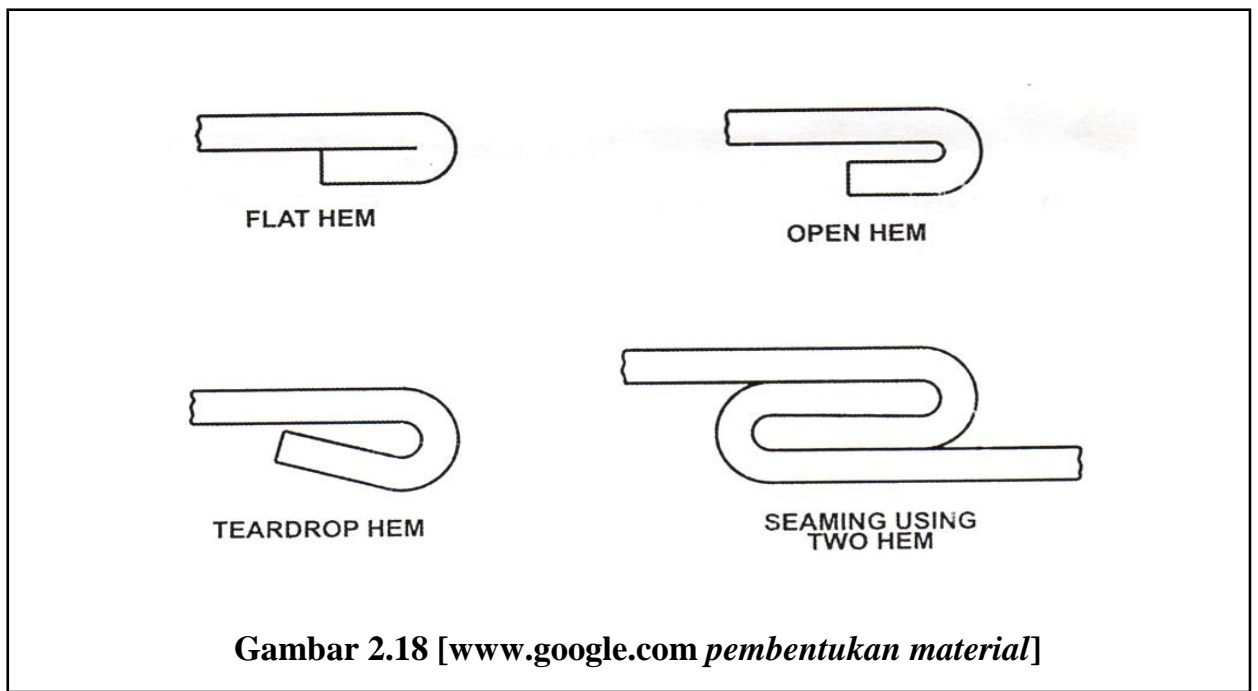

\section{Deep Drawing}

Sheet metal forming yang dilakukan dengan cara menekan sheet metal ke dalam suatu cetakan sehingga membentuk produk yang serupa dengan mangkok (cuplike product). bentuk akhir yang diinginkan sama dengan bentuk alat penekanannya tersebut.

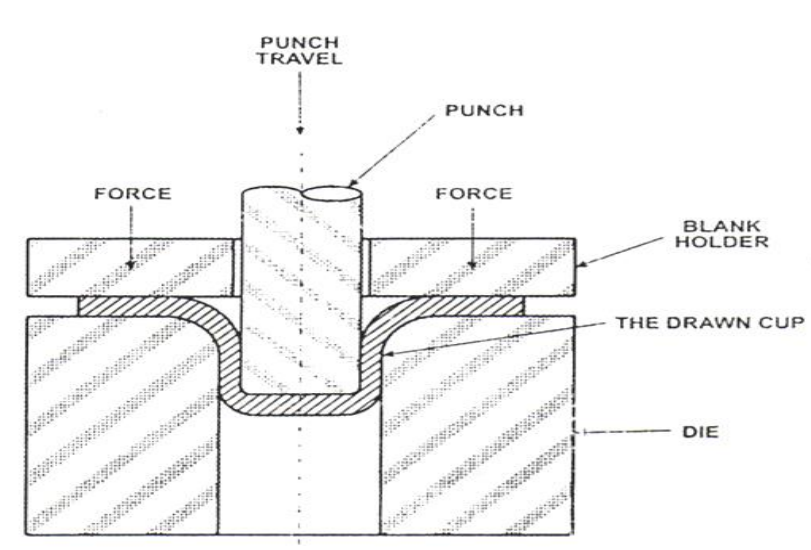

Gambar 2.19 [www.google.com pembentukan material] 


\section{PEMBENTUKAN MATERIAL (METAL FORMING) \\ HOT WORKING PROCESS DAN COLD WORKING PROCESS}

\section{Embossing}

Menekan sebagian permukaan sheet metal kedalam suatu bentuk cetakan. Bentuk penekan serupa dengan bentuk cetakan.

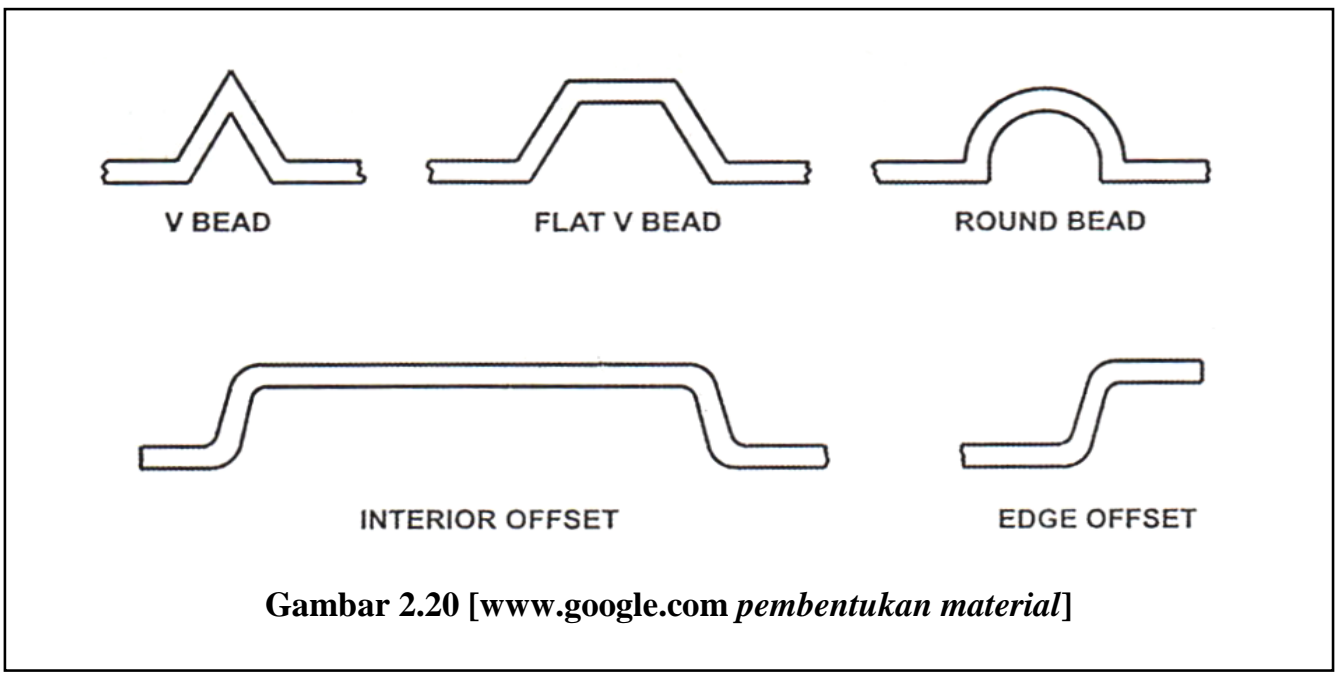

\section{E. Rubber Forming}

Dilakukan dengan cara menekan sheet metal kedalam suatu karet yang diletakan pada suatu wadah. Akibat penekanan tersebut, karet akan menekan material dengan tekanan yang merata pada seluruh permukaan material, sehingga material akan menempel pada seluruh permukaan penekan.
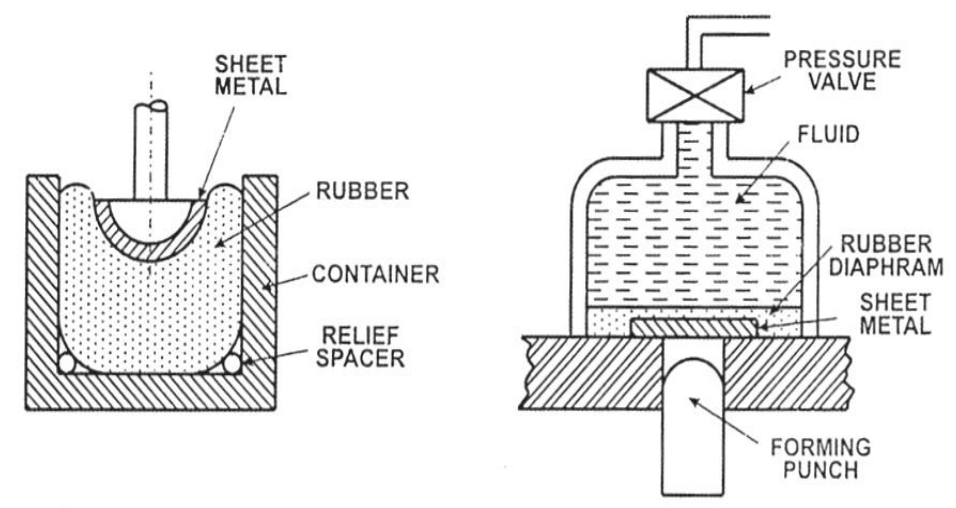

Gambar 2.21 [www.google.com pembentukan material] 


\section{PEMBENTUKAN MATERIAL (METAL FORMING) \\ HOT WORKING PROCESS DAN COLD WORKING PROCESS}

\section{DAFTAR PUSTAKA}

1. Sato, G. Takeshi dan Sugiarto, N.1999. Menggambar Mesin . Jakarta : Pradnya Paramita.

2. Staf Pengajar Tata Tulis Karya Ilmiah 2004. Tata Tulis Karya Ilmiah. 2004. Bandung : Departemen Sosioteknologi Institut Teknologi Bandung.

3. www.google.com / pembentukan material.

4. www.google.com/ proses pengelasan.

5. Irwan, Yusril,2010. Proses Pengelasan. Bandung.

6. Hidayat, W. (2019, April 2). ANALISIS TEGANGAN GESER, MOMEN DAN TEGANGAN LENTUR MAKSIMUM UNTUK PEMBUATAN PISAU PADA RANCANG BANGUN MESIN PEMECAH BUAH KAKAO KAPASITAS 2 TON/JAM. https://doi.org/10.31227/osf.io/nu64a

7. Hidayat, W. (2019, April 2). KLASIFIKASI DAN SIFAT MATERIAL TEKNIK SERTA PENGUJIAN MATERIAL.

https://doi.org/10.31227/osf.io/6bmfu 